\title{
Credit Risk Management and Deposit Money Banks Stability in Nigeria: Does Good Corporate Governance Matter?
}

\author{
Osasere Kindness BENCHARLES* $\quad$ Donald Chidi NWANKWO \\ Department of Banking and Finance, Faculty of Management Science, University of Benin, Benin \\ *Email of the corresponding author: kindososasere@gmail.com
}

\begin{abstract}
The study examined the impact of credit risk management on deposit money banks stability and the moderating role of corporate governance. The study period spanned 11 years (2009-2019) and twelve (12) deposit money banks were taken as sample for the study. Annual data from sampled banks were subjected to various statistical and empirical tests. The pooled model, random effect (REM) and fixed effect model (FEM) techniques of the panel least square was adopted for empirical testing while statistical testing was done using the descriptive statistics, unit root tests and co-integration tests. Credit risk management was measured using data on nonperforming loans (NPL), liquid ratio (LQR), capital adequacy ratio (CAR) and loan loss provisioning (LLP) while bank size (BS) was introduced as a control variable. Corporate governance was measured using data on audit committee independence (ACI). Banks stability was measured using the Z-score of sampled banks. Empirical result indicated that NPL had a negative insignificant relationship with bank stability and a positive insignificant relationship with bank stability when corporate governance was introduced. Other credit risk management variables (LQR, CAR, LLPR) were found to strengthen banks stability although their significance were mixed. Bank size was found to be negatively related with banks stability. Premise on research findings, the study concluded that credit risk management is germane to the stability of deposit money banks in Nigeria during the period of study. It was also concluded that corporate governance although having a positive relationship with banks stability has no significant impact. Among other things, the study recommended that detailed policies and procedures for non-performing loans exposure, management and recovery are in place so as to reduce the incidence of non-performing loans.
\end{abstract}

Keywords: Credit Risk, Bank Stability, Corporate Governance, Z-Score.

DOI: $10.7176 /$ RJFA/12-16-01

Publication date:August $31^{\text {st }} 2021$

\section{Introduction}

In recent times, the role played by financial institution in economic development cannot be down played. Financial institutions in general and banking institutions in particular carryout the role of financial intermediation by creating wealth and transferring such wealth from deficit to surplus unit through the extension of loans and advances. According to Da and Ghosh (2007), stability of the financial system plays an important role in elevating economic growth just as its collapse can have a devastating impact on the economy. Rwayitare, Shukla and Ruhara (2016) have described the activities of deposit money banks (DMB's) to be like blood arteries of the human body in developing economies especially in Nigeria as it accounts for a substantial part of its financial assets. Deposit money banks activities enhance commercial activities, facilitate an efficient payment system and serves as the main source of liquidity in the financial system (Cohen, 1986). A major channel in which banks creates wealth is through the advancing of loans in which they earn a commission. Banks are exposed to considerable risk when they carry out intermediation services and this risk includes credit risk, liquidity risk, market risk, legal risk, foreign exchange risk as well as operational risk. According to Gieseche (2004), credit risk requires adequate management as banks survival is a function of the efficient management of credit risk. Risk in the lay man's parlance can be used to refer to the uncertainty in business operations. Therefore credit risk according to Coyle (2000) is the risk stemming from the inability of debtors to repay what is owed as at when due.

An effective credit risk management centers on the practice of a good corporate governance (Surya, 2016). Corporate governance (CRG) according to Sreeti (2017) is the process through which the resources of the firm is allocated so as to maximize shareholders value. This assertion follows the earlier opinion of Emile Wolf International (2010) were it asserted that CRG is concerned with the management of firms resources with the shareholders interest in mind. Good corporate governance ensures that banks credit is managed so as to maximize shareholders fund and ensure banks stability (Baker \& Powell, 2009). This would imply that issues affecting liquidity, non-performing loans, loan loss provisioning and capital adequacy must be strictly dealt with in accordance with set out principles in the CRG code. Good corporate governance is expected to enhance the effectiveness of risk management, hence its financial stability. According to Sanusi (2012), banks collapse in the banking sector during the banking distress is attributable to poor credit quality which was as a result of poor CRG practices. Bank managers were reported to have rolled out credit facilities in large sums to individuals 
without the necessary collateral or provisions for loan losses. The impact of financial distress of 2008/2009 revealed that the so called "big" banks while showing financial strength on the outside were actually ailing financially as most of their outstanding loans were non-performing with increased incidence of bad debts with little or no provisions for loss (Eke, Akpanuko \& Umofffong, 2019). This led to the bank consolidation exercise in 2005 by the then CBN governor Sanusi Lamido who called for the merging and acquisitions of ailing banks and outright liquidation of distressed banks. Sequel to the consolidation exercise, various guidelines were rolled out aimed at curbing financial malpractices of executive officers as well as to ensure banks stability.

The risk taking behavior of deposit money banks (DMB's) in Nigeria became especially evident during the banking crisis. The significant dip in asset quality was found to have led to the devaluation of banks asset quality (BGL, 2010). Eventually, all banks were found to have liquidity problems arising from huge portfolio of nonperforming loans which lead to severe bank run (Owojori, Akintoye \& Adudu, 2011). The ripple effect of the $2008 / 2009$ financial crisis still lingers in the banking industry and continues to threaten banks stability (Adegbie \& Adebanjo, 2020). This is as a result of decline in credit management which led to an increase in nonperforming loans and bad debts (Sanusi, 2012).

Banks credit management practice was found to be wanting and thus triggered the banking distress in Nigeria. Sanusi (2012) claimed that some board members gave out loan facilities without adequate collateral. This assertion was confirmed by CBN report that most banks gave out loan without adequate security and no adequate provisions for loan loss were made. The lax credit standard of banks became a factor in the collapse of so many banks in Nigeria, and in some other cases banks mergers and acquisitions. Some of the affected banks were Afri-banks, Platinum-Habib bank, Equatorial trust bank, Intercontinental bank, Oceanic bank and so many banks numerous to mention (Chiejiine, 2010). Sanusi (2012) identified poor corporate governance (CRG) to be a major factor in banking distress, since effective credit risk management is based on strict adherence to corporate governance code. Following the banking consolidation of 2005, a code of CRG was issued to the banking industry to strengthen governance. One notable code was the need to separate the role of banks chief executive officer (CEO) from its board of director (duality). Prior to this code of governance, it was a major practice in banks for the CEO to be the board director making financial malpractice convenient and almost untraceable. This was the case of Cecilia Ibru, the then CEO and board director of defunct Oceanic bank who was accused of extending loans worth millions of naira to her house help. This therefore emphasizes the need of a strict corporate governance code to limit financial malpractices amongst banks executives. The relationship between corporate governance and credit management is not farfetched, since the effectiveness of credit management relies on the extent of adherence to a good corporate governance code (Sreeti, 2017).

Credit risk management has been found to have a major impact on banks profitability and stability. However, lots of empirical research has mainly focused on the relationship between credit risk management and profitability (Asiedu, 2019; Nwanna \& Oguezue, 2017; Gadzo, Oduro \& Asiedu, 2019; Ajao \& Oseyomon, 2019). While these studies succinctly established a relationship between credit risk management and profitability among various institutions understudied, there appear to be paucity in the literature as it concerns the relationship between credit risk management and banks stability. The issue of banks stability is worth considering as profitable banks could also be found to be financially unstable (Diaconu \& Oanea, 2015). However, few studies that have examined the relationship between credit risk and banks stability have been conducted outside of the Nigeria context (Afifa, 2018; Ameni, Hasna \& Mohammed, 2017; Afifa, 2017) thus necessitating a study to mirror the recent happenings in Nigeria. It is based on background that this study is aimed at examining the relationship between credit management and deposit money banks stability in Nigeria.

Studies on the role of corporate governance on banks credit risk management practice has also been up for empirical debate. Lots of studies have attempted to establish the impact of corporate governance on credit risk management or profitability (Permatasari, 2020; Li, Kong, Atuahene, Bentum-Micah \& Agyapong, 2020; Djebali \& Zakhdouch, 2019). While these studies succinctly provided empirical clarification as to their relationship, the studies were majorly on the relationship between corporate governance and profitability or credit risk management. Judging from recent happenings in the Nigeria banking sector which was highlighted before, the need to examine just how corporate governance mechanism moderates the relationship between credit management practice and banks stability becomes imperative. However, there also appear to be paucity in empirical evidence as to the moderating effect of corporate governance on the relationship between credit management and stability. It is in the light of this that this study attempts to investigate the impact of credit risk management on deposit money banks stability in Nigeria as well as the moderating effect of corporate governance on their relationship.

\section{Review of Literature and Development of Hypotheses} 2.1 Concept of Banks Stability

Banks stability focuses on the long-run survival of banks. A banking institution can have increasing profitability level and yet be considered financially unstable. Therefore, banks stability is defined as the absence of banking 
crisis ( Brunnermier, Crockett, Goodhart, Persaud and \& Shin, 2009). Ozili and Thankom (2018) define banks stability to be the absence of abnormal disruption in credit supply, payment systems and banking services. Barth, Caprio and Levine (2013) pointed out reasons why bank could become unstable. The study revealed that banks instability can be triggered by shaky regulation or ineffective supervision. Although strict supervision is highly recommended, the study noted that strict supervision did not lead to greater banking stability. Ozili (2018) investigated the determinants of banking stability in Africa banks and his study showed that the presence of foreign banks, banking efficiency, banking concentration, bank size, political stability were key determinants of banking stability.

Since profitability and stability tend to be used interchangeably, Anchor (2016) sought to identify the interrelationship between profitability and stability and the result showed that there is a negative relationship between profitability and stability. Hence, lower banks stability is expected to lead to higher profitability level. This result confirms the risk- return theory, where higher risk is found to lead to an increase in expected return. Berger and De Young (1997) identified bank efficiency to be a key determinant of bank stability. This implies that efficient banks are better able to manage credit risk as they can improve their stability by mitigating high non-performing loans. Githinji (2016) noted that "banks can become unstable because of low capital quality, low asset quality, associated with aggression of their credit policy that increases credit risk." The size of bank capital was found to determine banks ability to maintain stability during financial crisis ( Klaas \& Vagigova, 2014). Hodachnik (2009) observes that "banks stability is maintained by sufficient capitalization that is characterized by security level of risk asset and acts as the guarantor of bank reliability and liquidity. Bank stability can be measured with the Zscore coefficient which is based on five financial ratios that can be calculated from data found on banks annual bulletin. A high Z-score indicates high bank stability and lesser signifies probability of going bankrupt.

\subsection{Non-Performing Loans and Banks Profitability/Stability}

According to Kiriu (2013) nonperforming loans (NPL) can be referred to a non-performing asset (NPAs). Accordingly, Kiriu (2013) defines NPL to be a credit facility in respect of which the interest and principal amount has remained past due for a specific period of time. Bank loans serve as a major channel of wealth creation as interest payment and repayment of principal creates a steady source of income for the banks. When such loans are not being serviced for some time such loans is classified as nonperforming loan. According to Stuti and Bansal (2013), the performance of banks is reflected by the level of nonperforming loans. A decline in the level of nonperforming loans indicates that asset quality of banks is improving. On the other hand, an increase in NPL spells financial distress for such banks as NPL threatens banks stability and erodes banks profit through interest income loss and eventual write-off of the principal loan amount itself. Over the years, the Nigeria banking sector has gone through lots of financial instability which have lead to the distress of many banks. Much of the instability in Nigeria banks have been attributed to the increasing level of nonperforming loans held by banks (Omoruyi, 2018). Increasing levels of nonperforming loans have lead to reduction in banks profit, erosion of capital and poor asset quality" (Aminu, 2013).

According to Balasubramaniam (2013), nonperforming loans erodes time management as it takes time for management to prepare such loans which would have been used for other essential activities which would have brought good return. Again, NPL yields no interest to the bank instead it plunges management into spending as it cost management to institute specialized departments and hire specialized financial engineers to deal with NPLs. Micheal, Vasanthi and Selvarajn (2006) opines that NPL erodes operational efficiency hence profitability, liquidity and solvency positions of banks. Kroszner, (2002) found that NPL affect banking growth and survival and eventually bank failures if not properly managed. High NPL erodes banks capital base and therefore incapacitates the banks from undertaking risky projects and to realize potential productive ventures. The relationship between NPL and banks stability/profitability has been subject of empirical debate. Studies have found mixed result between NPL and bank stability. For example, studies carried out by Nyarko-Baasi (2018), Ozurumba (2016), Etale, Ayunku and Etale (2016) and Saba, Kouser and Azeem (2012) found a negative relationship between NPL and banks profitability and stability. It is in the light of this that this study develops the first hypothesis as;

Hypothesis One: There is no significant relationship between non-performing loans and deposit money banks stability in Nigeria.

\subsection{Loan loss Provision and Banks Stability}

Banks are faced with credit risk when they extend credit facilities to borrowers. The probability that borrowers will be unable to meet up principal/interest payment is known as credit risk. Therefore, to manage credit risk, bank will usually keep a specified amount as a cushion to absorb expected loss on bank's loan portfolio. The amount set aside by banks is what is termed "loan loss provision (LLP). Loan loss provision is a credit risk management tool used by banks to reduce expected loss on bank's loan portfolio. The provision of a cushion against loan loss becomes very important as banks credit extension makes them susceptible to loan default as a 
result of deteriorating economic conditions which impacts on borrower's ability to repay loan (Laeven \& Majinoni, 2003)

Loan loss provision plays a fundamental role in enhancing banks stability and soundness as they carry out lending. Banks are therefore expected to make sufficient provision for loan loss although there have been no specific definition as what is 'sufficient'. According to Beatty and Liao (2009), LLP is critical in assessing financial system stability as it is a major factor for the volatility in banks profitability and capital positions which has a bearing on banks supply of credit to the economy. One notable advantage of LLP is that even before the actual loss can be determined, LLP enables banks estimate loss from a particular loan portfolio. In other words, LLP should result in direct charges against earnings during upturns in the economic cycles as banks anticipate future losses on the loan portfolio when the economy hits a downturn". When these anticipated loan loss eventually crystallize, banks can then draw on these reserves, thereby absorbing the losses without impairing capital.

The main objective of LLP has been identified to include making forecast on banks future loan default, reduction of taxes through managing bank earnings and capital, managing volatility of income and earnings as well as reducing fluctuations in risk weighted asset that affects banks profitability and stability (Kanagaretnam \& Lobo, 2010; Norden \& Stoain,2013; Bouchekokoga, 2012). DMB's are expected to calculate or estimate losses that can arise from their loan portfolio and set aside a tangible amount as provision to absorb shocks brought about

Hypothesis Two: There is no significant relationship between loan loss provision and deposit money banks stability in Nigeria.

\subsection{Liquidity and Deposit Money Banks Stability}

The term liquidity is used to refer to the ability of firms to meet short term liability. Bencharles and Abubakar (2020) defined liquidity to be the ease at which banks liquidate its assets, borrow or use up its external reserve to meet short term liabilities. Liquidity therefore is the ability of banks to meet their financial commitments and maturing obligations within the stipulated time (Sathyamoorthi, Mapharing \& Dzimiri, 2020). The ability of banks to honor financial obligations as they become due without incurring loss from asset liquidation is also known as liquidity (Terseer, Henry \& Mkuma, 2020). Banks liquidity has been measured using different metrics in the finance literature. Some of these metrics includes current ratio (Baafi, et al, 2020), liquid asset to total asset, liquid asset to deposit ratio ( AlAli, 2020), cash and cash equivalent, cash to deposit ratio (Sathyamoorthi, et al, 2020), cash reserve ratio, loan to deposit ratio (Terseer, et al, 2020). This different metrics are used to examine different levels of liquidity. For example, while the cash to deposit ratio looks at how much cash is available to cover customer deposits, loan to deposit ratio looks at how much deposit has been used for loan.

Hypothesis Three: There is no significant relationship between liquidity and deposit money bank stability in Nigeria.

\subsection{Capital Adequacy Ratio and Deposit Money Bank Stability in Nigeria}

Regulatory agencies has established several rules and policies with the aim of fostering banks stability. Recently, financial institutions have been mandated to hold enough capital in order to sustain banks stability. The amount of statutory capital required to be held by financial institutions is known as the regulatory capital or capital adequacy (Jumreornvong, Chakreyavanich, Treepongkaruna \& Jiraporn, 2018). The reason for the mandatory capital is to protect banks against unexpected financial shocks and banks customers who become victims in the case of bankruptcy. Singh and Milan (2018) opines that the stability of the banks is determined by the amount of capital held since capital serves as a shock absorber in cases of unanticipated losses.

According to Jahan (2019) capital adequacy emphasizes the safeguarding of depositors and other creditors from the probable losses that a bank might experience and holding a sufficient amount, for a bank as well as mitigating all probable financial risks associated with market, credit, operation, interest rate, reputation, liquidity, strategy, environment etc. Capital adequacy guides bankers and banks regulators to mitigate any potential risk that bank may face. Capital adequacy has a vital role in dipping the number of bank failures. It also plays crucial role for minimizing various risk components in banking industry (AiAli, 2019).

Hypothesis Four: There is no significant relationship between capital adequacy ratio and deposit money banks stability in Nigeria

\subsection{Theoretical Review}

\subsubsection{The Commercial Loan Theory}

The commercial loan theory or real bills doctrine originates from the $18^{\text {th }}$ century economic thought by Adams Smith in his research "The Wealth of Nations". In the research, Smith advocated that commercial banks purchase and hold bills since these real bills are considered prudent assets. The commercial loan theory states that deposit money banks should grant short term self-liquidating productive loans to business firms. By self 
liquidating loan we refer to loans that are capable of funding production through its various stages i.e. storage, transportation and distribution. The loan is said to have self liquidated when the final goods are ultimately sold and the proceed used for repayment of the loan. (Bencharles \& Abubakar, 2020)

The theory also assert that the central banks should only lend to banks on the security of such short-term loans as this would ensure that banks keep proper degree of liquidity. The commercial loan theory is focused on influencing bank lending and economic activities. This theory is expected to act as a monetary tool to cushion money supply and economic activities. This theory have become popular in Nigeria banks, thus they are of the opinion that depositors money should be invested in short term loans since deposit funds are also repayable at short notice. (Teseer, et al, 2020)

\subsubsection{The Shiftability Theory}

The shiftability theory was propounded by H.G Moulton who opined that commercial banks keeps in its portfolio of asset a sizeable amount of asset that can easily be shifted to other banks without loss of capital. This theory tolls the same line as the commercial loan theory. The point of divesture of this theory from the commercial loan is where it shifts it focus from self liquidating bills to other open market asset that can be easily shifted to another entity such as the government securities ( Motim Masinde \& Mugend, 2012). This theory implies that banks holds short term market investment which can be quickly liquidated or sold off when the need for liquidity arises. The banks are also expected to hold assets that can be easily shifted to the central bank in the case of any liquidity crisis arising in the banking sector.

\subsubsection{The Anticipated Income Theory}

The anticipated income theory was developed by Prochanow (1944) following the standard practice of extending term loans in the commercial banks in the US. Following this theory, the nature and personal characteristics does not play much in extending loan, rather, loans are extended based on the anticipated income of the borrower (Afriyie \& Akotey, 2011). Unlike previous theories, where liquidation is by sales of borrower's asset or shifting loans to some other entity, this theory looks mainly at the anticipated income of the borrower. This would imply that banks should make loans based on the anticipated income of the borrower and not his present value.

\subsection{Empirical Literature}

Ogbulu and Eze (2016) investigated the effect of CRM on DMB's performance in Nigeria using the error correction framework to capture the relationship between variables while the Granger causality test was used to test for causal effect. Result findings indicated that CRM indicators were significant in explaining variations in ROE, ROA and return on shareholders' fund. The study also found no causal relationship between CRM and DMB's performance. The study of Ajayi and Ajayi (2017) sought to determine the impact of CRM on deposit money banks performance in Nigeria for the period 2001-2015. The panel least square methodology was used to capture the relationship between CRM and DMB's performance. The study found a negative relationship between CRM and DMB's performance in Nigeria.

Ogbulu and Eze (2016) investigated the effect of CRM on DMB's performance in Nigeria. The error correction framework was used to capture the relationship between variables while the Granger causality test was used to test for causal effect. Result findings indicated that CRM indicators were significant in explaining variations in ROE, ROA and return on shareholders' fund. The study also found no causal relationship between CRM and DMB's performance. The study of Ajayi and Ajayi (2017) sought to determine the impact of CRM on deposit money banks performance in Nigeria for the period 2001-2015. The panel least square methodology was used to capture the relationship between CRM and DMB's performance. The study found a negative relationship between CRM and DMB's performance in Nigeria.

Ajao and Oseyomon (2019) examined the impact of credit risk management and performance of banks in Nigeria. The study utilized the GMM and granger causality techniques. Result indicated a direct and significant relationship between DMB's credit risk management variables (NPL, capital adequacy, LLP). However, a significant negative relationship was found between liquidity and performance. Inebedion, Vincent and Obadiaru (2020) investigated the impact of risk management on financial firms in Nigeria. The GMM and VECM method were used to provide empirical findings. Result indicated a short run relationship between liquidity risk and performance and a long run relationship between credit risk, capital adequacy, leverage, liquidity risk and performance. Onyeiwu, Ajaji and Myoneke (2020) examined the impact of credit risk on banks profitability in Nigeria. The study employed the use of OLS to analyze data spanning 2012-2018. Result indicated the presence of a strong relationship between credit risk (capital adequacy \& NPL) and banks performance

Ogundayo, Oyedokun and Okwuosa (2020) investigated the impact of credit risk management on profitability of listed deposit money banks in Nigeria during the period 2013-2017. The study employed the use of multiple regression technique. Result indicated that credit risk management has a significant positive effect on banks profitability. Specifically, NPL was significantly negative, LLP was insignificantly positive while loan and advances had a significant positive impact on performance. Do, Ngo and Phung (2020) examined the impact of NPL on profitability of commercial banks in Vietnam. The study employed the use of ordinary least square 
with RE and FE models. Result indicated that NPL has a negative relationship with profitability. Loans to deposit and GDP were found to have a significant impact on performance.

Ndyagyenda (2020) investigated the impact of credit risk management and financial performance in Uganda. The study employed the use of ordinary least square. Result indicated that credit risk management impacts positively on financial performance of sampled banks. Munangi and Sibindi (2020) investigated the impact of credit risk on the financial performance of South African Banks for the period 2008-2018. Panel data techniques was employed for the study via the RE and FE models. Non-performing loans was found to have a negative relationship with performance, capital adequacy was found to have a positive relationship with performance.

\section{Methodology}

This study employs a causal research and longitudinal design. Causal research design because this study looks at the relationship between sets of variables and longitudinal design because its uses historic time series data of credit risk management and other variables for a period of 10years (2009-2019). This study focuses on the impact of credit risk management on the stability of deposit money banks in Nigeria for the period 2009 to 2019. The population of the study consists of the twenty one (21) banks in the Nigeria banking sector in which only thirteen (13) are listed in the Nigeria stock exchange. Twelve (12) of these banks is sampled for this study.

Relevant cross sectional (Panel) data are sourced and computed from the annual reports of the sampled banks spanning 2009 to 2019. Data collected are return on asset, liquidity ratio, bank size, non-performing loans and loan loss provision ratio, capital adequacy, return on asset and return on equity and data on corporate governance.

\subsection{Model Specification and Measurement of Variables}

This study specifies two models to capture the effect of credit risk management on deposit money banks stability. The functional form of our study is adapted from the study of Ajao and Oseyomon (2019). Their model was specified as;

$\mathrm{ROA}=\mathrm{f}(\mathrm{CAR}, \mathrm{LQR}, \mathrm{NPLR}, \mathrm{LLPR})$

Where

$\mathrm{ROA}=$ Return on Asset

$\mathrm{CAR}=$ Capital Adequacy Ratio

LQR = Liquidity Ratio

NPLR $=$ Non-performing Loan ratio

LLPR $=$ Loan loss provision ratio

Our study adapts the aforementioned study model but modifies by first looking at the relationship between credit risk (capital adequacy, loan loss provision, non-performing loan, liquidity) and banks stability (Z-score) and then the moderating role of corporate governance on the relationship between credit risk and banks stability. The functional form of our model is then given as;

$B S T B=f(C R M)$

Where;

$\mathrm{CRM}=$ Credit risk management and is a vector of credit risks.

$\mathrm{CRG}=$ Corporate governance (Audit committee independence)

Expanding equation (1) we have

$B S T B=f(N P L, L L P, C A R, L Q R, B S)$

Where;

BSTB $=$ Bank stability

NPL $=$ Non performing loan

LLP $=$ Loan Loss Provision

$\mathrm{CAR}=$ Capital Adequacy

$\mathrm{LQR}=$ Liquidity

$\mathrm{BS}=$ Bank Size and it's a control variable.

Equations (2) and (3) are expressed in mathematical form and cannot be estimated in this form. In other to make them compliant for a regression analysis and estimation, equations (3.2) and (3.3) are expressed linearly/econometrically as follows;

$B S T B_{i t}=\beta_{0}+\beta_{1} N P L_{i t}+\beta_{2} L L P_{i t}+\beta_{3} L Q R_{i t}+\beta_{4} C A R_{i t}+\beta_{5} B S_{i t}+\varepsilon_{i t}$

$B S T B_{i t}=\alpha_{0}+\alpha_{1} N P L^{*} C R G_{i t}+\alpha_{2} L L P_{i t}+\alpha_{3} L Q R_{i t}+\alpha_{4} C A R_{i t}+\alpha_{5} B S_{i t}+\varepsilon_{i t}$

Where;

$\alpha_{0}, \beta_{0}=$ Regression Intercept

$\beta_{1}-\beta_{5}=$ Beta coefficient to be estimated (Main effect) 
$\alpha_{1}-\alpha_{5}=$ Beta coefficient to be estimated (interaction terms between corporate governance and credit risk management.

$\varepsilon_{i t}=$ Idiosyncratic shock

$\mathrm{i}, \mathrm{t}=$ cross sections, $2009-2019$

Equation (5) and (6) are modeled to capture the impact of credit risk management on deposit money banks stability in Nigeria and the moderating role of corporate governance. The beta coefficients are is expected to bear the following signs. Coefficients $\mathrm{B}_{1}$ (NPL) is expected to be negatively signed $\left(\mathrm{B}_{1}<0\right)$ since most theoretical and empirical literature have found a negative relationship between this two (Ozurumba, 2016; Tahir, 2014; Comfort \& Bassey, 2015) $\mathrm{B}_{2}$ (LLP), $\mathrm{B}_{3}$ (LQR), $\mathrm{B}_{4}$ (CAR) are expected to be positively signed and impact on banks stability (Akbas \& Karaduman, 2012; Dogan, 2013). The coefficient $\alpha_{1}$ (interaction term) is expected to be significant indicating that corporate governance (audit committee independence) enhances the effect of credit risk management (NPL) on banks stability. The measurements of the variable is presented in table 3.1

Table 3.1 Measurement of Variables

\begin{tabular}{|c|c|c|}
\hline Variables & Abbreviations & Measurements \\
\hline \multirow{2}{*}{ Bank Stability } & \multirow{2}{*}{ Z-Score } & $R O A+C A R$ \\
\hline & & $\sigma(R O A)$ \\
\hline Non Performing Loan & NPL & Nonperforming loan \\
\hline Loan Loss Provision & LLP & Loan loss provision \\
\hline Bank Size & $\mathrm{BS}$ & $\begin{array}{l}\text { Natural logarithm of total } \\
\text { asset value }\end{array}$ \\
\hline \multirow{2}{*}{ Liquidity Ratio } & \multirow{2}{*}{ LR } & Current asset \\
\hline & & $\overline{\text { Current liability }}$ \\
\hline \multirow{2}{*}{ Capital Adequacy } & \multirow{2}{*}{$\mathrm{CA}$} & T1er 1 Cap101 + T1er 2 Capial \\
\hline & & Risk -We1ghted Assets \\
\hline Corporate Governance & CRG & $\begin{array}{l}\text { Corporate governance is measured by Audit committee } \\
\text { independence }(\mathrm{ACI}) \text {. ACI is measured as the number of } \\
\text { independent non-executive directors to total number of persons in } \\
\text { the committee }\end{array}$ \\
\hline
\end{tabular}

Source: Authors compilation

\subsection{Method of Data Analysis}

The study begins by first conducting statistical test to ascertain the background characteristics of the dataset. The descriptive statistics is used to check for both the distribution and normality of the variables. This is followed by the Huasman test to ascertain the appropriate that best fit the study. The panel least square analytical method is then employed to analyze the model specified for the study. The panel least square is a panel version of the ordinary least square and is thus based on the underlying assumptions governing the least square methods. This method has been chosen as it has the ability to avoid multicollinearity problems, its use of higher degree of freedom results in least biased estimates. The use of panel least square has its advantages and one notable advantage of this method over the ordinary least square is its use of more observations as compared to the least square methods.

\section{Results and Discussion}

4.1 Descriptive Statistics

\begin{tabular}{lccccc}
\hline Variables & Mean & Std.Dev & Maximum & Minimum & P-value (Jaque Bera) \\
BSTB & 12.41 & 5.88 & 34.1 & 2.3 & 0.00 \\
CAR & 18.88 & 5.80 & 36.1 & 4.5 & 0.36 \\
LRR & 20.18 & 4.29 & 29.6 & 9.6 & 0.38 \\
LLPR & 3.07 & 2.74 & 10.2 & 0.03 & 0.00 \\
NPLR & 10.73 & 3.62 & 22.3 & 1.6 & 0.00 \\
BS & 156.85 & 795.39 & 9110.0 & 9.2 & 0.00 \\
ACI & 4.60 & 0.78 & 6.00 & 4.00 & 0.00 \\
Observation & 129 & 129 & 129 & 129 & 129
\end{tabular}

\section{Source: Authors computation from E-views 10}

The descriptive statistics for the variables in this study is presented in the table 4.3 .2 above. The table reports that sampled banks has a z-score averaging 12.41. While there is no one specific or regulatory requirement of z-score for banks although banks with higher score implies that the bank is considerably stable. 
Comparing the maximum value of 34.1 and the minimum score of 2.3 indicates that some banks were considerably more stable than others during the period of study. The standard deviation of 5.88 showed that there were little variations in the score of sampled banks from one period to another. Capital adequacy ratio of sampled banks during the period of study is averaged at 18.88. This value is higher than the regulatory requirement set out by the $\mathrm{CBN}$ and Basel committee indicating the compliance of sampled banks to the requirement of capital adequacy. Some sampled banks were found to have gone below this bench mark as shown by the minimum value of 4.5 .

The liquid ratio was found to have a mean of 20.18 during the period of study. This is as against the stipulated liquid ratio of $30 \%$ stipulated by the CBN. However, the maximum value showed that some banks operated close to this margin while other operated very far from it as indicated by the minimum value of 9.6. This is expected from banks as low liquid ratio is expected to enhance profitability levels although such act threatens the stability of the bank. The non-performing loan ratio is found to be relatively low for the banks taken taking together as indicated by the mean value of 10.73 . However, when we consider the maximum value, some banks had non-performing loan ratio (NPLR) of above $22 \%$ of total gross loans. The loan loss provision was found to be low and inadequate as the table reports a value of $3.07 \%$ of total gross loans. This value indicates that only $3 \%$ of the gross loan loss was provided for and when we compare that to the total amount of NPLR it becomes clear why banks stability was relatively low.

The banks sampled for this study are found to vary largely in size as indicated by the standard deviation of bank size (795.3). This indicates that the sampled banks do not have the same size and this is expected to influence its relationship with bank stability. Audit committee is found to be largely independent as indicated by the mean value of 4.60 . The result indicates that for the entire banks taken together, the minimum number of external auditor in the committee is four (4) and judging from the maximum value of 6 , the result also suggests that most of the audit committee members were external. The Jaqu Berra test shows that most of the variables are not normally distributed as indicated by the small p.values recorded making it impossible to reject the null hypothesis of normal distribution. This abnormality stems from the panel structure of the study since different banks had different characteristics.

\subsection{Regression Analysis}

Three distinct panel analytic regression models is used to estimate the relationships so as to enhance the robustness of the study. This model consists of the pooled regression model, fixed effect and random effect model. The pooled regression mainly has constant coefficients, referring to both intercepts and slopes. For this model this study would pool all of the data and run an ordinary least squares regression model. The fixed effect model is the differences across cross-sectional units that can be captured in differences in the constant term and the intercept term of the regression model varies across the cross sectional units. On the other hand, in the random effect model, the individual effects are randomly distributed across the cross-sectional units and in order to capture the individual effects, the regression model is specified with an intercept term representing an overall constant term.

Table 4.3.5A Regression Summary Model 1 (without moderating variable)

\begin{tabular}{|c|c|c|c|c|c|c|c|c|c|}
\hline \multirow[t]{2}{*}{ Variables } & \multicolumn{3}{|c|}{ Pooled Model } & \multicolumn{3}{|c|}{ Fixed Effect Model } & \multicolumn{3}{|c|}{ Random Effect Model } \\
\hline & Coeff & t-stat & Prob. & Coeff & t-stat & Prob. & Coeff & t-stat & Prob. \\
\hline NPLR & -0.07 & -0.86 & 0.38 & -0.07 & -0.59 & 0.55 & -0.00 & -0.00 & 0.99 \\
\hline LRR & 0.41 & 4.32 & $0.00 * *$ & 0.53 & 4.69 & $0.00 * *$ & 0.46 & 4.43 & $0.00 * *$ \\
\hline CAR & 0.36 & 3.90 & $0.00 * *$ & 0.43 & 5.47 & $0.00 * *$ & 0.39 & 5.24 & $0.00 * *$ \\
\hline BS & -0.00 & -0.68 & 0.49 & -0.00 & -0.64 & 0.52 & -0.00 & -0.88 & 0.37 \\
\hline LLPR & 0.39 & 2.25 & $0.02 *$ & 0.17 & 1.06 & 0.28 & 0.28 & 1.73 & 0.08 \\
\hline $\mathrm{C}$ & -3.35 & -0.58 & 0.56 & -6.73 & -2.20 & $0.02 *$ & -4.99 & -1.68 & 0.09 \\
\hline $\begin{array}{l}\text { R-Square } \\
\text { Adjusted R- }\end{array}$ & 0.27 & -1.16 & 0.24 & 0.42 & & & 0.30 & & \\
\hline Square & 0.25 & & & 0.36 & & & 0.27 & & \\
\hline F-Statistics & 9.6 & & & & & & 10.8 & & \\
\hline (Prob) & $(0.00)^{* *}$ & & & $6(0.00)^{* *}$ & & & $(0.00)^{* *}$ & & \\
\hline Hausman Test & & & & $\begin{array}{l}\mathrm{Chi}^{2} \\
11.61(0.04)\end{array}$ & & & & & \\
\hline
\end{tabular}

Source: Authors computation (2021)

Note: * and ** signify significance at the $5 \%$ and $1 \%$ level

The outcome of the panel estimations of the relationship between credit risk management and banks stability are summarized in the table above. Generally, the fixed effect model (FEM) is the preferred model as indicated by the large value of chi-square and low p-value of the Hausman test. However, the pooled and random 
effect model (REM) is discussed to enhance the robustness of this study. The R-squares of the model are moderate considering it is panel based estimation. However, the FEM is found to have the highest explanatory power indicating that some variables may vary over time, but fixed across firms. The F-statistics indicates that the variables are posses a linear relationship and that the model is significant overall. This result indicates that our estimations are fit for policy implications.

The result indicates that NPL is negatively signed in all models estimated (PM, FEM, FEM). It is also found that the co-efficient of NPLR is very low across the three models estimated indicating that the effect of NPLR on banks stability is minimal during the period of study. Explicitly, the result (FEM) indicates that a unit change in non-performing loan will cause a 0.07 change in banks stability. However, the relationship between NPLR and banks stability is found to be insignificant across all models estimated (PM, FEM, REM). As expected, liquid ratio (LRR) is found to enhance banks stability during the period of study. This result is found to be identical across all models estimated (PM, REM \& FEM) and found to be statistically significant at the $1 \%$ level. Specifically from the FEM model, a unit change in LRR will cause a significant fluctuation in banks stability by 0.53 . This implies that increased liquidity positions strengthens banks stability as funds are readily available to honor short or long term liabilities limiting any possible runs to the bank. The coefficient of LRR is found to be quite high indicating that the liquid positions of banks is germane in keeping banks stability.

Capital adequacy ratio is found to poses the expected sign and is statistically significant. This result is found to be identical across all three models estimated. This result implies that a unit shock in CAR would result to a corresponding change in banks stability by $0.36,0.43$ and 0.39 as shown respectively by the three models estimated. These coefficients are also large indicating that capital adequacy is very germane to the stability of sampled banks during the period of study. Loan loss provision (LLP) which is another factor tested against bank stability is found to be positively signed and statistically significant when samples are pooled together although not significant under the FEM and REM assumptions. This insignificance of this variable could be as a result of the poor loan provisioning as indicated in the summary statistics. However, LLP has the ability to enhance banks stability since it's provides necessary cushion against shocks of NPL. Bank size which is a control variable is found to be negatively signed and not statistically significant. This is against the a priori of this study and this relationship could be attributed to the fact that the banks used for this study are unequally sized and the heterogeneous nature of the banks might be responsible for this negative relationship.

Model 2 (Moderating for corporate governance)

Table 4.3.5B Regression Summary

\begin{tabular}{|c|c|c|c|c|c|c|c|c|c|}
\hline Variables & Poole & Iodel & & Fixed & fect $M$ & & Rand & Effect & odel \\
\hline & Coeff & t-stat & Prob. & Coeff & t-stat & Prob. & Coeff & t-stat & Prob. \\
\hline NPLR*ACI & 0.030 & 1.04 & 0.29 & 0.016 & 0.57 & 0.56 & 0.023 & 0.84 & 0.39 \\
\hline LRR & 0.40 & 3.71 & $0.00 * *$ & 0.14 & 1.19 & 0.23 & 0.29 & 2.69 & $0.00 * *$ \\
\hline CAR & 0.37 & 4.68 & $0.00 * *$ & 0.33 & 4.28 & $0.00 * *$ & 0.34 & 4.60 & $0.00 * *$ \\
\hline LLPR & 0.45 & 2.57 & $0.01 *$ & 0.24 & 0.96 & 0.33 & 0.41 & 2.14 & $0.03 *$ \\
\hline BS & -0.00 & -1.16 & 0.24 & -0.00 & -0.79 & 0.42 & -0.00 & -1.07 & 0.28 \\
\hline $\mathrm{C}$ & -5.61 & -1.94 & 0.05 & 1.54 & 0.48 & 0.63 & -2.41 & -0.83 & 0.40 \\
\hline R-Square & 0.28 & & & 0.47 & & & 0.22 & & \\
\hline Adjusted R-Square & 0.25 & & & 0.39 & & & 0.19 & & \\
\hline F-Statistics (Prob) & $\begin{array}{l}9.74 \\
(0.00)\end{array}$ & & & $\begin{array}{l}6.25 \\
(0.00)\end{array}$ & & & $\begin{array}{l}7.02 \\
(0.00)\end{array}$ & & \\
\hline Hausman Test & & & & $\begin{array}{l}\mathrm{Chi}^{2} \\
12.14 \\
(0.03)\end{array}$ & & & & & \\
\hline
\end{tabular}

Source: Authors computation (2021)

Note: * and ** signify significance at the $5 \%$ and $1 \%$ level

The table shows the relationship between credit risk management and banks stability when corporate governance is used as a moderating variable. The fixed effect model (FEM) is the preferred model as indicated by the high value of chi-square and low p-value of the Hausaman test. However, the pooled and random effect model (REM) would be discussed to enhance the robustness of this study. The R-squares of the model are moderate considering that it is panel based estimation. The F-statistics indicates that study variables are linear in nature and the model is significant overall.

The relationship between non-performing loan and bank stability when corporate governance (audit committee independence) interacts with non-performing is found to be positive although insignificant and this pattern is found to be identical across all models estimated. The co-efficient of NPLR is also found to be smaller when corporate governance is introduced with the exception of the REM were the coefficient is found to be a little larger. Specifically from the result (FEM), a unit change in non-performing loan is found to lead to a 0.01 
change in bank stability. The liquid ratio of sampled banks is found to be positively signed and significant in the REM and PM panel. However, liquid ratio was equally positively signed in the FEM panel although not significant. A unit change in liquid ratio would lead to a 0.14 change in banks stability, indicating that a unit change in liquid ratio would lead to a positive change in bank stability.

Capital adequacy ratio (CAR) is found to be positively significant with banks stability. This relationship is found to be identical across all models estimated. A unit change in the capital adequacy ratio is thus expected to lead to a 0.33 change in bank stability. Higher capital adequacy ratio is thus expected to improve banks stability. Loan loss provision (LLP) is found to be positively signed, indicating a positive relationship with banks stability. A unit change in loan loss provision is expected to lead to a $0.24 \%$ change in banks stability. However, this relationship is found to be insignificant at the $1 \%$ and $5 \%$ respectively. Finally, bank size is found to be negatively related with bank stability. This evidence that bigger banks are more likely to be unstable. However, the coefficients are found to be very small and statistically insignificant. This indicates that bank size is not significant in explaining changes in bank stability of sampled banks.

\subsection{Test of Hypotheses}

The various research hypotheses in the previous chapters would be tested using the estimated co-efficient presented in table 4.3.5A\&B. The various signs and level of significance would give the empirical backdrop for rejecting or accepting the hypotheses.

Hypothesis One: There is no significant relationship between nonperforming loans and banks stability in Nigeria.

The significance of the estimated coefficient of non-performing loan given in table 4.3.5A would serve as the empirical backdrop for testing this hypothesis. The coefficient of non-performing loan is found to be negative and not statistical significant $(0.55>0.05)$. Therefore, there is no enough statistical evidence to reject the above stated null hypothesis, we therefore conclude that there is no significant relationship between non performing loans and banks stability among deposit money banks during the period of study.

Hypothesis Two: There is no significant relationship between loan loss provision and banks stability in Nigeria. The significance of the estimated co-efficient of loan loss provision given in table 4.3.5A would serve as the backdrop for testing this hypothesis. The coefficient is found to be positive and not statistically significant at the $1 \%$ level $(0.28>0.05)$. We therefore have no statistical evidence to reject the above stated hypothesis and we conclude that there is no significant relationship between loan loss provision and banks stability among deposit money banks in Nigeria during the period of study.

Hypothesis Three: There is no significant relationship between liquidity ratio and banks stability in Nigeria. In testing this hypothesis, we focus on the coefficient and significance of liquidity ratio in the estimates in Tables 4.3.5A. In the result, the coefficient is positive and significant at the 1 percent level (judging from the probability of the t-values, which are less than 0.01). The study thus has enough evidence to reject the above stated hypothesis and accept the alternate that there is a significant relationship between liquidity ratio and banks stability in Nigeria.

Hypothesis Two: There is no significant relationship between capital adequacy ratio and banks stability in Nigeria.

In testing this hypothesis, we focus on the coefficient of capital adequacy in the estimates in Tables 4.3.5A. In the result, the coefficient is positive and significant at the 1 percent level (judging from the probability of the $\mathrm{t}$ values, which are less than 0.01 ). This study reject the null hypothesis and accepts the alternate and conclude that there is a significant relationship between capital adequacy ratio and banks stability among deposit money banks in Nigeria.

Hypothesis Four: Corporate governance has no significant moderating effect on the relationship between credit risk management on banks stability.

The estimate found at table 4.3.5B would serve as the backdrop for testing this hypothesis. From the table, it is found that interaction between non-performing loans and corporate governance is not significant although positive. Therefore, this study is unable to reject the null hypothesis and conclude that corporate governance has no significant moderating effect on the relationship between credit risk management and banks stability among deposit money banks in Nigeria.

\subsection{Discussion of Findings}

The outcome of this study is found to be robust and fitting for policy recommendations. Specifically, the study revealed that sampled banks were relatively stable during the period of study. Such stability could be attributed to the compliance of banks to various statutory requirement of the $\mathrm{CBN}$. Banks were found to have adequate capital ratio to absorb financial shocks during the period of study. The study also found that non-performing loan was at its minimum during the period of study. On the contrary it was found that banks had a relative low provisioning for loan loss which might have influenced its non-statistical significance on banks stability. 
The regression results were found to be equally robust and adequate in capturing the relationship between credit risk management and banks stability. Specifically, non-performing loan was found to be negatively related with banks stability in the first model thus indicating a destabilizing effect of non-performing loan on banks stability. However, with the interaction of corporate governance variable, non-performing loan was found to be positive. This is indicative that audit committee independence has a cushioning effect on non-performing loans, which led to the positive relationship between non-performing loan and banks stability it was also observable that the magnitude of impact of non-performing loan on banks stability was found to have reduced after it was made to interact with corporate governance (audit committee independence). The coefficient was found to have decreased (0.07-0.01) indicating that audit committee independence is capable of reducing the incidence of nonperforming loan since independent committees are better able to carry out their function with transparency without management intervention. This result is in line with apriori and is in conformity with the studies of Ozili (2018), Etale, Ayunku and Etale (2016), and Ozurumba (2016) where a negative relationship between nonperforming loans and banks stability/profitability were submitted.

The study also found liquid ratio to have a positive significant relationship with bank stability with the absence of corporate governance indicator. Similar trend was found in the second model when corporate governance was moderated. Result indicated that liquid ratio became insignificant although still found to have a positive relationship with banks stability. This positive relationship is in line with apriori and confirms the studies of Baafi, et al (2020), AlAli (2020) and Sathyamoorthi, et al (2020) which found a positive relationship between liquidity and banks stability/performance.

Capital adequacy ratio (CAR) was found to have a significant positive relationship with bank stability. Specifically, the relationship CAR and banks stability were found to positive in both models estimated. The implication of this is that higher capital adequacy ratio is germane in absorbing the shock caused by nonperforming loans and hence strengthens banks stability. This study is at tandem with the studies of AlAli (2019), Abdul (2017) and Jahan (2019) that found a positive relationship between capital adequacy ratio and banks performance viz a viz banks stability and profitabilty. However, this study deviates from the study of Kamran, Omran and Arshad (2019) that found a negative relationship between capital adequacy and banks performance. A positive insignificant relationship between loan loss provisioning and banks stability was observable during the course of this study. Result indicated that loan loss provisioning (LLP) was positive and insignificant in the two models estimated. This could be as a result of the low amount of LLP made by banks during the period of study. It also implies that LLP has no significant impact on banks stability during the period of study. This outcome is in tandem with the study of Pelealu and Worang (2018) were loan loss provisioning was found to have no significant relationship with banks performance. However, this study outcome negates the study of Mustafa, Ansari and Younis (2018) were a significant relationship was found between loan loss provisioning and banks performance. Finally, bank size was found to have a negative insignificant relationship with banks stability in the two models estimated. This indicates that bigger banks do not necessarily indicate stability rather bigger banks are only stable when they conform to stipulated guidelines as regards credit risk management regulations as well as corporate governance. This result is in conformity with the study of Adusei (2015).

\section{Conclusion and Recommendations}

This study examines the impact of credit risk management on banks stability as well as the moderating role of corporate governance among deposit money banks in Nigeria. This study was necessitated by the alarming distress and failures that faced the Nigeria banks which led to the recapitalization and consolidation of the Nigeria banking sector. Credit mismanagement viz a viz increasing incidence of non-performing loans, low capital ratios, poor loan loss provisioning as well as low liquidity were found to have limited the financial runs on banks. This study was carried out to check the impact of the aforementioned variables on the bank stability of banks as well as to check how corporate governance practice has helped moderate this relationship. A panel data structure was used in the empirical analysis with data on twelve (12) deposit money banks spanning 2009-2019 and to achieve this, a panel framework was devised for the analysis and the pooled, random effect and fixed effect models were chosen in estimating the models specified for the study. Estimates obtained were found to be robust to both specifications and data manipulations. Premise on the findings of this study, we conclude that credit risk management is germane to the stability of deposit money banks in Nigeria during the period of study. Secondly, this study concludes that corporate governance while it was found to downplay the incidence of nonperforming loans among deposit banks during the period of study, its effect on banks stability was found to be insignificant.

On recommendations, this study recommends that detailed policies and procedures for non-performing loans exposure, management and recovery are in place so as to reduce the incidence of non-performing loans. Deposit money banks must also follow standard corporate governance by ensuring that the audit committee is largely independent from management control especially as it has been found that audit committee independence has a cushioning effect on non-performing loans. Secondly, banks management must ensure that they implement 
a sound methodology that facilitates the identification, measurement, monitoring and control of liquidity levels since it affects banks stability. Thirdly, banks must conform to stipulated capital ratios provided by regulatory authorities and good corporate governance must be practiced by banks with particular reference to the board management since they have the ability to influence the level of capital adequacy of the bank. Finally, this study recommends that adequate provisions be made for loan loss so as to further enhance banks overall stability.

\section{References}

Adegbie, F., \& Adebanjo, S. (2020), "Credit risk management and financial stability in quoted deposit money banks in Nigeria", European Journal of Accounting, Auditing and Finance Research, 8(8), 1-29

Afriyie, H., \& Akotey, J. (2011), "Credit risk management and profitability of selected rural banks in Ghana, Catholic University College of Ghana, 3, 1-18

AiAli, M.S. (2020), "Liquidity management and banks performance in Kuwait" Financial Markets, Institutions and Risks, 4(3), 105-111.

Ajao, M.G., \& Oseyomon, E.P. (2019), "Credit risk management and performance of deposit money banks in Nigeria", African Review of Economics and Finance, 11(1), 157-177

Ajayi, L., \& Ajayi, F. (2017), "Effects of credit risk management on performance of deposit money banks in Nigeria", International Journal of Research in Management \& Business Studies, 4(3), 50-55

Akbas, H., \& Karaduman, H. (2012), "The effect of firm size on profitability: An empirical investigation on Turkish manufacturing companies", European Journal of Economics, Finance and Administrative Sciences, $55,21-27$

Aminu, B. (2013), "Consolidation and asset quality of banks in Nigeria”, International Journal of Business and Management Invention, 2 (2), 12-20

Baafi, J., Duodu, J., Sarkodie, E., Boadie, W. (2020), "Examining the economic interaction between liquidity and firms financial performance: Evidence from the Ghana Exchange", Journal of Economics, Management and Trades, 26(10), 34-46

Baker, H.K., \& Powell, G.E. (2009), "Management views on corporate governance and firm performance", Advances in Financial Economics, 13, 83 - 118.

Batra, S. (2003), "Developing the Asian markets for non-performing assets-developments in India", In 3rd Forum on Asian Insolvency Reform (FAIR), Seoul, Korea, November (pp.10-11

Beatty, A., \& Liao, S. (2009), "Regulatory capital ratios, loan loss provisioning and procyclicality. Columbus, United States: Ohio State University. Mimeographed document.

Bencharles, O., \& Abubakar, B. (2020), "Liquidity management and its impact on Islamic and conventional banks profitability in Nigeria: A comparative study", IOSR Journal of Economics and Finance, 11(4), 1020.

BGL Banking Report (2010). Getting Banks to Lend Again. London: Financial Times Limited.

Bouchekoua, A., Matoussi, H., \& Trabelsi, S. (2012), "Monolithic versus Differential Impacts of Sox Regulation on Market Valuation of Banks' Loan Loss Provision. Proceedings from the CAAA Annual Conference 2012

Chiejine, C. (2010), "Corporate governance in the banking sector: An analysis of the 2009 regulator intervention and operators behavior", Journal of Finance, 1(1), 1-2.

Cohen, B. (1986), "In whose Interest"? International banking and American foreign policy, New Haven, CN: Yale University Press. In Lall R. (2009), (eds) Why Basel II Failed and Why any Basel III is Doomed. GEG working paper 2009/52: 3-4.

Comfort, E., \& Bassey, G. (2015), "Bank profitability and liquidity management: A case study of selected Nigerian deposit money Banks", International Journal of Economics, Commerce and Management, 3(4), $342-366$

Coyle, B. (2000), "Framework for credit risk management", Chartered Institute of Bankers, United Kingdom

Das, A. \& Ghosh, S. (2007), "Determinants of credit risk in Indian state-owned banks: An empirical investigation", Economics and Statistics, 58(2), 355- 372.

Doğan, M. (2013), "Does Firm Size Affect The Firm Profitability?” Evidence from Turkey. Research Journal of Finance and Accounting, 4(4), 53-59.

Doh, H., Ngo, T., \& Phung, Q. (2020), "The effect of non-performing loans on profitability of commercial banks", A Case of Vietnam. Accounting, 6, 373-386.

Emile Wolf International (2010). Audit and assurance. Berkshire, UK stream: Emile Wolf Publishing Ltd.

Gadzo, S., Oduro, R., \& Asiedu, M. (2019), "Credit risk on corporate financial performance: Evidence from listed banks on the Ghana stock exchange", Journal of Economics and International Finance, 2(3), 21-35

Hodachnik, G. (2009), "Foreign experience in diagnosing the crisis situation in the banking sector", Management in Russia and Abroad, 4, 11-16.

Ikpefan, O. A. (2012), "The impact of bank capitalization in the performance of Nigerian banking Industry", The Journal of Commence, 4(1), 2220-6043. 
Inegbedion, H., Vincent, B., \& Obadiaru, E. (2020), "Risk management and the financial performance of banks in Nigeria", International Journal of Financial Research, 11(5), 115-128.

Jahan, N. (2019), "Influence of capital adequacy on the growth of banking sector in Bangladesh", ICTACT Journal on Management Studies, 5(4), 1125-1132

Juumreornvong, S., Chakreyavanich, C., Treepongkaruna, S., Jiraporn, P. (2018), "Capital adequacy, deposit insurance and the effect of their interaction on bank risk", Risk and Financial Management, 11(79), 1-18.

Kanagaretnam, K., \& Lobo, G. (2010), "An empirical analysis of auditor independence in the banking industry" The Accounting Review, 86(6), 20111-2046. http://dx.doi.org/10.2308/accr.2010.85.6.2011

Karkowska, R., Acedański, J. (2019), "The effect of corporate board attributes on bank stability", Portuguese Economic Journal, 2(1), 1-39

Klaas, J., \& Vagizova, V. (2014), “Tools for assessing and forecasting financial stability of the commercial bank under conditions of instability", Investment Management and Financial Innovations (4), 157-163

Kroszner, P. (2002), "Non-performing loans, monetary policy and deflation: The industrial country experience", Economic and Social Research Institute Cabinet Office, Government of Japan

Li, K., Kong,Y., Atuahene, S., Bentum-Micah, G., \& Agyapong (2020), "Corporate governance and banking stability: The case of universal banks in Ghana", International Journal of Economics and Business Administration, 8(1), 325-352.

Michael, J., Vasanthi, G., \& Selvaraju, R. (2006), "Effect of non-performing assets on operational efficiency of central-cooperative banks", Indian Economic Panorama, 6(3), 33-39.

Munangi, E., \& Sibindi, A. (2020), "An empirical analysis of the impact of credit risk on the financial performance of South African banks", Academy of Accounting and Financial Studies Journal, 24(3), 1-15

Ndyagyenda, C. (2020), "Credit risk management and financial performance: A case of banks of Africa", Open Journal of Business and Management, 8, 30-38.

Norden, L., \& Stoian, A. (2013), "Bank earnings management through loan loss provisions. A double-edged sword"? Working Paper, Amsterdam.

Nwanna, O., \& Oguezue, C. (2017), "Effect of credit management on profitability of deposit money banks in Nigeria”, International Institute of Academic Research and Development, 137

Nyarko-Baasi, M. (2018), "Effects of non-performing loans on the profitability of commercial banks - a study of some selected banks on the Ghana Stock Exchange", Global Journal of Management and Business Research, 18 (2), 39-47

Ogbulu, M., \& Eze, P. (2016), "Credit risk management and the performance of deposit money banks in Nigeria: an error correction analysis", Applied Economics and Finance, 3(2), 97-109.

Ogundayo, G., Oyedokun, G., \& Okwuosa, I. (2020), "Credit risk management and profitability of listed deposit money banks in Nigeria", African Journal of Corporate Governance Research, 1(1), 86-105.

Onyeiwu, C., Ajayi, G., \& Muoneke, O. (2020), "The impact of credit risk on banks profitability in Nigeria", Journal of banking and financial economics, 1(13), 5-22.

Owojori, A. A., Akintoye, R. I., \& Adidu, A. F. (2011), "The challenge of risk management in Nigeria banks in the post Consolidation era", Journal of Accounting and Taxation, 13(2), 23-31.

Ozili, P. K. (2018), "Banking stability determinants in Africa", International Journal of Managerial Finance, $14(4), 462-483$

Ozili, P. K., \& Thankom, A. G. (2018), "Income smoothing among European systemic and non- systemic bank", The British Accounting Review, 50(5), 539-558

Ozurumba, B. (2016), "Impact of non-performing loans on the performance of selected Commercial banks in Nigeria”, Research Journal of Finance and Accounting, 7(16), 95-109

Permatasari, I. (2020), "Does corporate governance affect bank risk management? A Case of Indonesian Bank", International Trade, Policies and Development, 4(2), 127-139.

Rwayitare, B., Shukla, J., \& Ruhara, C. (2016), "Credit risk and commercial bank profitability in Rwanda", International Journal of Advance Research, 4(9), 294-325.

Saba, I., Kouser, R. \& Azeem, M. (2012), “Determinants of non-performing loans: Case of US Banking Sector”, International Journal of Banking and Finance, (44), 479-488

Sanusi, L. (2012), "Central Bank of Nigeria report on the Collapse of Banking Sector. Abuja: Press Release

Sathyamoorthi, C., Mapharing, M., \& Dzimiri, M. (2020), "Liquidity management and financial performance: Evidence from commercial banks in Botswana", International Journal of Financial Research, 11(5), 399413

Sreeti, R. (2017), “Corporate Governance: Concepts and Issues. Retrieved from https://www.iodonline.com/Articles/corporate\%20Governance\%20and\%20Sustainab ility\%20Concepts\%20Sreeti\%20Raut.pdf.

Stuti, M., \& Bansal, S. (2013), “An analysis of non-performing assets in Indian Banking sector”, Research Journal of Business and Research, 8(2), 34-39. 
Surya, B. G. (2016), “Corporate governance and firm performance: Empirical evidence from India”, Journal of Business and Management Research, 1(2), 48-65.

Tan, Y., Floros, C., \& Anchor, J. (2017), "The profitability of Chinese banks: Impacts of risk, competition and efficiency", Review of Accounting and Finance, 16(1), 86-115.

Terseer, W., Henry, Y., \& Mkuma, Y. (2020), "Effect of liquidity management on the financial performance of banks in Nigeria", European Journal of Business and Innovation Research, 8(4), 30-44.

Ukinaamemen, A., \& Ozekhome, H. (2019), "Does capital adequacy influence the financial performance of listed banks in Nigeria"? Oradea Journal of Business and Economics, 5(2), 69-80. 